\title{
Effect of Extractant and Temperature on Phenolic Compounds and Antioxidant Activity of Selected Spices
}

\author{
Khalil I. Ereifej1, Hao Feng1, Taha M. Rababah2, Sufyan H. Tashtoush2, \\ Muhammad H. Al-U'datt ${ }^{2}$, Sana Gammoh'2, Ghaid J. Al-Rabadi ${ }^{3}$ \\ ${ }^{1}$ Department of Food Science and Human Nutrition, University of Illinois, Urbana-Champaign, Urbana, USA \\ ${ }^{2}$ Faculty of Agriculture, Jordan University of Science and Technology, Irbid, Jordan \\ ${ }^{3}$ Department of Animal Production, Faculty of Agriculture, Mutah University, Al-Karak, Jordan \\ Email: ereifej@just.edu.jo, kereifej@illinois.edu
}

Received 10 November 2015; accepted 25 April 2016; published 28 April 2016

Copyright (C) 2016 by authors and Scientific Research Publishing Inc.

This work is licensed under the Creative Commons Attribution International License (CC BY).

http://creativecommons.org/licenses/by/4.0/

c) (i)

Open Access

\section{Abstract}

Ten spices marketed in Jordan, (Syzygium aromaticum L., Coriadrum sativum L., Cuminum cyminum L., Zingiber officinale Rosc., Elettaria cardamomum, Curcuma longa, Rhus coriaria L., Cinnamomum zeylanicum Blume, Foeniculum vulgare Mill and Laurus nobilis L.) were investigated for their phenolic compounds and antioxidant activity. The influence of different extractants (methanol, ethanol and acetone) at different temperatures $\left(20,40\right.$ and $\left.60^{\circ} \mathrm{C}\right)$ was examined. Results showed at $60^{\circ} \mathrm{C}$ using methanol, cloves had the highest level of total phenolics $(781.0 \mathrm{mg} \mathrm{GAE} / 100 \mathrm{~g}$ using acetone). At $40^{\circ} \mathrm{C}$, sumac and cloves had the highest amounts of total phenolics (343.9 $\mathrm{mg} / 100 \mathrm{~g}$ and $342 \mathrm{mg} \mathrm{GAE} / 100 \mathrm{~g}$ respectively). At $20^{\circ} \mathrm{C}$, cloves continued to have the highest amount of total phenolics $(394.7 \mathrm{mg} / 100 \mathrm{~g})$ using methanol as extactant. Ethanol as extractant, cloves gave the highest level of phenolics (548 mg GAE $/ 100 \mathrm{~g}, 493.4 \mathrm{mg} \mathrm{GAE} / 100 \mathrm{~g}$ ) at $60^{\circ} \mathrm{C}$, while at $20^{\circ} \mathrm{C}$ cloves and sumac showed the highest concentrations of phenolics $(350.8 \mathrm{mg} \mathrm{GAE} / 100 \mathrm{~g}$ and $342.8 \mathrm{mg} \mathrm{GAE} / 100 \mathrm{~g}$ respectively). Acetone as extractant at $60^{\circ} \mathrm{C}$, cloves had the highest levels of phenolics $(781 \mathrm{mg} \mathrm{GAE} / 100 \mathrm{~g})$ while at $40^{\circ} \mathrm{C}$ and at $20^{\circ} \mathrm{C}$, sumac contributed the highest levels of total phenolics $(583.2 \mathrm{mg} \mathrm{GAE} / 100 \mathrm{~g}$ and $754.5 \mathrm{mg} \mathrm{GAE} / 100 \mathrm{~g})$. The total phenolics concentration varied significantly among the spices. Their values varied according to the extractant and extracting temperature. $\mathrm{IC}_{50}$ (radical scavenging activity) reflecting the antioxidant activity was presented. Results showed that cloves had the highest antioxidant activity while the cinnamon, turmeric and sumac had a appreciable level of antioxidant activity. Green cardamom and coriander had the lowest antioxidant activity. Antioxidant activity was positively correlated with total phenolic compounds content of the investigated spices. 


\section{Keywords}

\section{Phenolic Compounds, Antioxidant Activity, Spices, Solvents, Extractant, Temperature}

\section{Introduction}

Spices are one class of the aromatic plants; they are mainly present in the tropical provinces; the spices could be either as seeds, flowers or leaves [1]. On the other hand, herbs are fragrant and non-woody plants in which they are used in flavoring food dishes; the herbs could be leaves, stems or seeds. These additives are supplemented in small amounts to the food to enhance the flavor. Nutritionally, the spices and herbs are significant in reducing the peroxidation of lipids, which is the change (off-flavor) in the nature and the chemical composition of lipids during the processing, preservation and the final preparation of foods [2]. Spices prevent the lipid oxidation process due to the presence of natural antioxidants [3] [4].

The impact of antioxidants in spices exceeds the prevention of the oxidation process to influence the health of humans [5]. Several medicinal studies proved that they promote health and the immunity of humans; the existence of phytochemicals such as the phenolic compounds in plants, protect humans from cancers, depression, inflammations as well as their significance in treating heart diseases [5]. The phytochemicals are usually used to refer to the compounds found in plants that are not required for normal functioning of the body. Formally, the phytochemicals are defined as bioactive substances from plants which have beneficial effect on human health [6] [7].

Phytochemicals are bioactive substances of plants that have been associated in the protection of human health against chronic degenerative diseases [8]. The consumption of fruits and vegetables is associated with lower risk of cancer, heart disease, hypertension and stroke. This has been attributed to the presence of phytochemicals and antioxidants in food. These phytochemicals may be present in small amounts but are very important to the health of consumers.

The antioxidant property in many plants is related to the presence of phenolic compounds. Nutritionally, these compounds are responsible for increasing the shelf life of foods as well as slowing the lipid, protein and enzymatic oxidation. In addition, phenolic compounds reduce the rancidity development, which prevent off-flavor of foods [9]. Antioxidants are specific additives that inhibit oxidation through reacting with free radicals; hence; forming inactive products. Antioxidants are any substance that prevents the rancidity or other flavor decline. The types of antioxidants are the natural and synthetic antioxidants; both of these additives include phenolic compounds [10]. Extraction of phenolic compounds using variety of solvent systems, time and temperature combination showed that the levels of extracted phenolics always depend on extractant, temperature, method of phenol extraction and their interaction.

This work aims to determining the levels of phenolic compounds in several spices marketed in Jordan. The project also will evaluate the influence of different extraction solvents and extraction temperatures on the concentrations of these compounds.

\section{Materials and Methods}

\subsection{Spices Samples}

About $500 \mathrm{~g}$ of the investigated spices (Table 1) were purchased from a local market, in Irbid city in Jordan. All the spices were purchased twice with two months time interval. Their scientific and local names were obtained from different references. All the purchased spices were pulverized to a fine powder using a laboratory mill to pass a $0.5 \mathrm{~mm}$ sieve and kept at $4^{\circ} \mathrm{C}$ in Ziploc plastic bags until time of analysis.

\subsection{Extract Preparation}

The extractants of the investigated spices were prepared by using three different solvents (methanol, ethanol and acetone) to investigate the effect of solvent on phenolic compounds levels at three different temperatures (20, 40 and $60^{\circ} \mathrm{C}$ ) for each extractant.

One gram of each spice was weighed out and extracted with $50 \mathrm{ml}$ of methanol. Extraction was carried out 
Table 1. The investigated spices marketed in Jordan.

\begin{tabular}{cccc}
\hline English Name & Scientific Name & Plant Family & Used Part \\
\hline Cloves & Syzygium aromaticum L. & Myrtaceae & Ripe fruits \\
Coriander & Coriadrum sativum L. & Apiaceae & Fruit (seeds) leaves \\
Cumin & Cuminum cyminum L. & Apiaceae & Fruits (seeds) \\
Ginger & Zingiber officinale Rosc. & Zingiberaceae & Fleshy rhizome \\
Green Cardamom & Elettaria cardamomum & Zingiberaceae & Seeds \\
Turmeric & Curcuma longa L. & Zingiberaceae & Rhizome \\
Sumac & Rhus coriaria L. & Anacardiaceae & Dried fruits \\
Cinnamon & Cinnamomum zeylanicum Blume & Lauraceae & Stem bark \\
Sweet Cumin, (Fennel) & Foeniculum vulgare Mill & Apiaceae & Seeds, leaves \\
Sweet Laurel, (Sweet Bay leaf) & Laurus nobilis L. & Lauraceae & Leaves \\
\hline
\end{tabular}

under stirring for 60 minutes at $60^{\circ} \mathrm{C}$. Each one was filtered using filter paper into a $50 \mathrm{ml}$ volumetric flask, the volume was made up to mark using the same extractant and kept in the dark at refrigerated temperature until the time of analysis.

\subsection{Phenolic Compounds Determination}

The Folin-Ciocalteu assay [11] was used to determine the total content of phenolic compounds. Folin-Ciocalteu reagent is not specific to detect all phenolic groups found in the extracts. The total phenolic compounds were assayed calorimetrically:, $0.2 \mathrm{ml}$ of spice extract (two replicates) were transferred into a test tube, then mixed with $0.4 \mathrm{ml}$ of $10 \%$ diluted Folin-Ciocalteu reagent, after three minutes $0.8 \mathrm{ml}$ of a $10 \%$ solution of sodium carbonate as a buffer was added and mixed well, all the tubes were allowed to stand for one hour at room temperature. The absorbance was measured at $725 \mathrm{~nm}$ using the spectrophotometer (CE CELL, model 1020). A mixture of reagents without the sample was used as a blank. The phenolic compounds content was expressed as gallic acid equivalents (mg GAE/100g) on dry weight basis; the gallic acid was used to prepare a calibration curve. Gallic acid standard was used to prepare the standard curve as follow; $200 \mathrm{mg}$ of gallic acid were dissolved in $20 \mathrm{ml}$ of distilled water, $0,10,25,50,100,200$ and 400 ppm concentrations, were prepared, all reagents wereadded as above and the absorbance was read at $725 \mathrm{~nm}$.

\subsection{Effect of Extraction Solvent}

Organic solvents; methanol, ethanol and acetone were used to extract phenolic compounds from the spices. One gram of each spice was weighed out and subjected to extraction. Extraction was done under stirring while holding one extraction temperature: 20,40 and $60^{\circ} \mathrm{C}$ for one hour at constant level. Each one was filtered using filter paper into a $50 \mathrm{ml}$ volumetric flask, kept in the dark at refrigerated temperature until the time of analysis.

\subsection{Effect of Extraction Temperature}

Approximately, one gram of each spice was subjected to extraction at $20^{\circ} \mathrm{C}, 40^{\circ} \mathrm{C}$ and $60^{\circ} \mathrm{C}$. Extraction was done under stirring while using one extraction solvent; methanol, ethanol and acetone. The extraction time was 60 minutes. Each one was filtered using filter paper into a $50 \mathrm{ml}$ volumetric flask, kept in the dark at refrigerated temperature until the time of analysis.

\subsection{Radical DPPH Scavenging Activity}

DPPH (2,2-diphenyl-1-picrylhydrazyl)radical scavenging was estimated according to the method of Mättaus [12]. The scavenging effect of DPPH was followed by monitoring the decrease in absorbance at $515 \mathrm{~nm}$ that occurs due to the reduction by the antioxidants or reaction with a radical species. Approximately, $2 \mathrm{~g}$ (two rep- 
licates) of each spice sample were extracted under stirring with $50 \mathrm{ml}$ methanol for 60 minutes, at $60^{\circ} \mathrm{C}$. Different levels of methanol extracts $(10,25,50,100$, and $200 \mu \mathrm{g} / \mathrm{ml})$ of each spice were reacted with $0.2 \mathrm{ml}$ of DPPH (50 mg of DPPH in $100 \mathrm{ml}$ methanol). The mixture was brought to a total volume of $4.0 \mathrm{ml}$ with the extracting solvent. The mixture was mixed thoroughly and allowed to stand in the dark for 30 minutes. Absorbance (A) was read at $515 \mathrm{~nm}$, against the blank. $\mathrm{IC}_{50}$ (the efficient concentration of spice extract in $\mathrm{mg} / \mathrm{ml}$ required to decrease initial DPPH radical concentration by $50 \%$ ) was obtained by interpolation from linear regression analysis.

\section{Statistical Analysis}

The collected data were statistically analyzed using analysis of variance (ANOVA), using the general linear model procedure of SAS institute [13]. Data for each test were analyzed as a Complete Randomized Block Design (CRBD). Differences among treatment means were separated using the Least Significant Differences (LSD) at $\mathrm{p} \leq 0.05$.

\section{Results and Discussion}

\subsection{Effect of Extraction Solvent}

Tables 2-4 show data on total phenolic compounds content extracted by different solvents; methanol, ethanol and acetone at 60,40 and $20^{\circ} \mathrm{C}$. Data shows that total phenolic compounds concentrations had been affected significantly by the extractant used and temperature employed. Total phenolic concentrations ranged between 6.1 (coriander) and $305.5 \mathrm{mg} \mathrm{GAE} / 100 \mathrm{~g}$ (cloves) when the methanol was used as extractant at $60^{\circ} \mathrm{C}$. All other spices found to have intermediate values (Table 2).

When ethanol was used, phenolic concentrations showed higher values than the methanolic extractant. Cloves, sumac and cinnamon had the highest values (548.0, 317.4 and $214.5 \mathrm{mg}$ GAE/100g, respectively), whereas; green cardamom, coriander, cumin and ginger had the lowest concentrations (8.4, 13.8, 20.8 and $23.2 \mathrm{mg} \mathrm{GAE} /$ $100 \mathrm{~g}$, respectively).

The phenolic compound levels in cloves found to be the highest as compared with values for other spices when acetone was used as extractant (781.0 mg GAE/100g) followed by sumac, cinnamon, turmeric and ginger (725.1, 293.4, 164.4 and $33.5 \mathrm{mg}$ GAE/100g, respectively). Whereas, green cardamom, coriander and sweet laurel had the lowest values (4.5, 5.6 and $9.1 \mathrm{mg} \mathrm{GAE} / 100 \mathrm{~g}$ respectively).

Phenolic compounds concentrations extracted by methanol, ethanol and acetone showed a significant variation among the investigated spices, except for cumin and sweet cumin, the phenolic compounds content showed

Table 2. Effect of extraction solvent on total phenolic compounds contents at $60^{\circ} \mathrm{C}^{\mathrm{a}}$.

\begin{tabular}{|c|c|c|c|c|}
\hline \multirow{2}{*}{ Spices } & \multicolumn{3}{|c|}{ Total Phenolics at $60^{\circ} \mathrm{C}$} & \multirow[b]{2}{*}{ LSD at $p \leq 0.05$} \\
\hline & Methanol & Ethanol & Acetone & \\
\hline Cloves & $305.5^{c^{*}}$ & $548.0^{\mathrm{b}}$ & $781.0^{\mathrm{a}}$ & 53.2 \\
\hline Coriander & $6.1^{\mathrm{b}}$ & $13.8^{\mathrm{a}}$ & $5.6^{\mathrm{b}}$ & 1.9 \\
\hline Cumin & $20.8^{\mathrm{a}}$ & $20.8^{\mathrm{a}}$ & $14.8^{\mathrm{a}}$ & 8.7 \\
\hline Ginger & $38.2^{\mathrm{a}}$ & $23.2^{\mathrm{b}}$ & $33.5^{\mathrm{ab}}$ & 11.0 \\
\hline Green Cardamom & $23.1^{\mathrm{a}}$ & $8.4^{\mathrm{b}}$ & $4.5^{\mathrm{c}}$ & 3.4 \\
\hline Turmeric & $45.1^{\mathrm{c}}$ & $82.9^{\mathrm{b}}$ & $164.4^{\mathrm{a}}$ & 13.4 \\
\hline Sumac & $238.6^{\mathrm{c}}$ & $317.4^{\mathrm{b}}$ & $725.1^{\mathrm{a}}$ & 68.6 \\
\hline Cinnamon & $121.6^{c}$ & $214.5^{\mathrm{b}}$ & $293.4^{\mathrm{a}}$ & 18.7 \\
\hline Sweet Cumin & $18.3^{\mathrm{a}}$ & $14.5^{\mathrm{a}}$ & $10.7^{\mathrm{a}}$ & 12.6 \\
\hline Sweet Laurel & $29.0^{\mathrm{b}}$ & $47.3^{\mathrm{a}}$ & $9.1^{\mathrm{c}}$ & 17.3 \\
\hline
\end{tabular}

${ }^{a}$ Means are average of two replicates and expressed as mg of gallic acid/100g on dry weight basis. ${ }^{*}$ Means with different letters in the same row are significantly different at $\mathrm{p} \leq 0.05$. 
Table 3. Effect of extraction solvent on phenolic compounds contents at $40^{\circ} \mathrm{C}^{\mathrm{a}}$.

\begin{tabular}{ccccc}
\hline \multirow{2}{*}{ Spices } & \multicolumn{3}{c}{ Total Phenolics at $\mathbf{4 0}{ }^{\circ} \mathbf{C}$} & \\
\cline { 2 - 5 } & Methanol & Ethanol & Acetone & LSD at p $\leq \mathbf{0 . 0 5}$ \\
\hline Cloves & $342.0^{\mathrm{a}^{*}}$ & $493.4^{\mathrm{a}}$ & $445.2^{\mathrm{a}}$ & 159.0 \\
Coriander & $13.7^{\mathrm{a}}$ & $10.8^{\mathrm{ab}}$ & $7.2^{\mathrm{b}}$ & 5.0 \\
Cumin & $35.8^{\mathrm{a}}$ & $17.0^{\mathrm{b}}$ & $27.2^{\mathrm{ab}}$ & 16.9 \\
Ginger & $41.7^{\mathrm{a}}$ & $19.8^{\mathrm{b}}$ & $22.5^{\mathrm{b}}$ & 16.7 \\
Green Cardamom & $8.8^{\mathrm{a}}$ & $8.4^{\mathrm{a}}$ & $2.9^{\mathrm{a}}$ & 21.0 \\
Turmeric & $43.5^{\mathrm{c}}$ & $77.2^{\mathrm{b}}$ & $123.6^{\mathrm{a}}$ & 158.7 \\
Sumac & $343.9^{\mathrm{b}}$ & $339.3^{\mathrm{b}}$ & $583.2^{\mathrm{a}}$ & 61.2 \\
Cinnamon & $182.1^{\mathrm{b}}$ & $160.0^{\mathrm{b}}$ & $315.1^{\mathrm{a}}$ & 13.2 \\
Sweet Cumin & $17.0^{\mathrm{a}}$ & $10.4^{\mathrm{a}}$ & $18.4^{\mathrm{a}}$ & 4.0 \\
\hline
\end{tabular}

${ }^{a}$ Means are average of two replicates and expressed as mg of gallic acid/100g on dry weight basis. "Means with different letters in the same row are significantly different at $\mathrm{p} \leq 0.05$.

Table 4. Effect of extraction solvent on total phenolic compounds contents at ambient temperaturea

\begin{tabular}{ccccc}
\hline \multirow{2}{*}{ Spices } & \multicolumn{3}{c}{ Total Phenolics at 20 ${ }^{\circ} \mathbf{C}$} & \\
\cline { 2 - 5 } & Methanol & Ethanol & Acetone & LSD at p $\leq \mathbf{0 . 0 5}$ \\
\hline Cloves & $394.7^{\mathrm{a}^{*}}$ & $350.8^{\mathrm{b}}$ & $279.8^{\mathrm{c}}$ & 27.0 \\
Coriander & $26.8^{\mathrm{a}}$ & $9.8^{\mathrm{b}}$ & $23.0^{\mathrm{a}}$ & 4.5 \\
Cumin & $43.8^{\mathrm{a}}$ & $19.0^{\mathrm{b}}$ & $26.9^{\mathrm{b}}$ & 15.7 \\
Ginger & $44.2^{\mathrm{a}}$ & $23.8^{\mathrm{b}}$ & $41.5^{\mathrm{a}}$ & 8.1 \\
Green Cardamom & $6.8^{\mathrm{a}}$ & $7.5^{\mathrm{a}}$ & $9.4^{\mathrm{a}}$ & 31.2 \\
Turmeric & $32.9^{\mathrm{b}}$ & $105.0^{\mathrm{a}}$ & $53.2^{\mathrm{b}}$ & 89.4 \\
Sumac & $271.4^{\mathrm{b}}$ & $342.8^{\mathrm{b}}$ & $754.5^{\mathrm{a}}$ & 62.5 \\
Cinnamon & $187.1^{\mathrm{a}}$ & $78.8^{\mathrm{b}}$ & $169.8^{\mathrm{a}}$ & 5.0 \\
Sweet Cumin & $25.5^{\mathrm{a}}$ & $10.3^{\mathrm{b}}$ & $11.3^{\mathrm{b}}$ & 9.5 \\
Sweet Laurel & $0.9^{\mathrm{c}}$ & $52.9^{\mathrm{a}}$ & $18.3^{\mathrm{b}}$ & \\
\hline
\end{tabular}

${ }^{a}$ Means are average of two replicates and expressed as mg of gallic acid/100g on dry weight basis. ${ }^{*}$ Means with different letters in the same row are significantly different at $\mathrm{p} \leq 0.05$.

similar values with different solvents. At $60^{\circ} \mathrm{C}$, acetone proved to be anexcellent extractant for cloves, sumac, cinnamon and turmeric (781.0, 725.1, 193.4 and $164.4 \mathrm{mg}$ GAE/100g respectively). While ethanol was excellent extractant for coriander and sweet laurel (13.8 and $47.3 \mathrm{mg}$ GAE/100g respectively). But methanol was suitable extractant for cumin, ginger, green cardamom and sweet cumin (20.8, 38.2, 23.1 and $18.3 \mathrm{mg}$ GAE/100g respectively).

As shown in Table 3 the phenolic compounds content extracted at $40^{\circ} \mathrm{C}$ using methanol, ethanol and acetone, the total phenolic compounds content varied significantly among the extractants. Acetone found to be a superior extractant for phenolics from sumac, cloves, cinnamon and turmeric (583.2, 445.2, 315.1 and $123.6 \mathrm{mg}$ $\mathrm{GAE} / 100 \mathrm{~g}$ respectively) at $40^{\circ} \mathrm{C}$. Followed by methanol as extractant for coriander, cumin, ginger, and green cardamom; (13.7, 35.8, 41.7 and $8.8 \mathrm{mg}$ GAE/100g respectively). Ethanol was suitable extractant for sweet laurel at $40^{\circ} \mathrm{C}$ (42.4 $\left.\mathrm{mg} \mathrm{GAE} / 100 \mathrm{~g}\right)$. 
Table 4 shows the effect of different extractants (methanol, ethanol and acetone) on the total phenolic concentrations at the ambient temperature $\left(20^{\circ} \mathrm{C}\right)$. The data depict that the three solvents significantly influenced the levels of phenolic compounds. When methanol was used as extractant at $20^{\circ} \mathrm{C}$, the highest value of phenolic contentwas for cloves (394.7 mg GAE/100g), and the lowest value was for sweet laurel (0.9 mg GAE/100g). Cloves had the highest value of phenolic compounds when ethanol was used as extractant (350.8 mg GAE/100g), and the lowest value for phenolics was found in green cardamom (7.5 mg GAE/100g). On the other hand, sumac gave the highest concentration of phenolic compounds (754.5 mg GAE/100g) when acetone was the extractant, while green cardamom had the lowest concentration (9.4 mg GAE/100g) among the spices at $20^{\circ} \mathrm{C}$.

Data proved that total phenolic compounds concentrations varied significantly according to extractant type and the temperature of extraction. This is in agreement with Hayouni et al. [14] and Hsu et al. [15] who reported that different extracting solvents influenced the total phenolic concentrations, which can be explained as a result of polarity of the solvent and thus different extractability among the phenolic compounds.

The level of total phenolic compounds for 36 vegetables and spices using $80 \%$ aqueous ethanol at room temperature, were studied [16], among them, turmeric, ginger, coriander, their values were higher than those obtained in this study, probably that was due to water ethanol mixture. Phenolic compound in spices like any other plant material, occur in groups or subgroups having different polarity which will influence the effectiveness of the solvent at a given temperature, and that explains why extraction of the same spice using the same solvent yields different level of phenolic compounds using different temperatures.

Shan et al. [17] studied the total phenolic compounds concentrations in cinnamon, coriander, cumin, sweet laurel and cloves, despite variation in extraction circumstances and the extraction temperature, our values are slightly higher than their values.The microbiological status and the chemical composition of the investigated spices were studied [18].

\subsection{Effect of Extraction Temperature}

Table 4 shows data on the concentrations of phenolic compounds extracted at $20^{\circ} \mathrm{C}, 40^{\circ} \mathrm{C}$ and $60^{\circ} \mathrm{C}$ using methanol as extractant. Cloves, ginger, turmeric, sumac, cinnamon and sweet laurel did not vary significantly by using different temperatures.

The highest concentrations of phenolic compounds were obtained by methanol at ambient temperature from cloves, sumac and cinnamon (394.7, 271.4 and 187.1 mg GAE/100g respectively). When the temperature was $40^{\circ} \mathrm{C}$; the maximum extraction of phenolic compounds from sumac was $343.9 \mathrm{mg} \mathrm{GAE} / 100 \mathrm{~g}$ ). However, $60^{\circ} \mathrm{C}$ was better for obtaining the extraction of phenolic compounds from green cardamom, turmeric and sweet laurel (23.1, 45.1 and $29.0 \mathrm{mg}$ GAE/100g respectively). The highest phenolic compounds content in cloves, coriander, cumin, ginger, cinnamon and sweet cumin were detected at ambient temperature as compared with 40 and $60^{\circ} \mathrm{C}$.

Table 2 shows the effect of temperature on the total phenolic compounds extracted by ethanol. The data show that there were no significant differences by different temperature especially for cumin, green cardamom, sumac, sweet cumin and sweet laurel. The rest of the spices varied significantly in total phenolic compounds using different temperatures. On the other hand, cloves, sumac and cinnamon showed significantly the highest content of phenolic compounds at $60^{\circ} \mathrm{C}$ (548.0, 317.4 and $214.5 \mathrm{mg} \mathrm{GAE} / 100 \mathrm{~g}$ respectively), followed by $40^{\circ} \mathrm{C}$ and at the ambient temperature, respectively.

The highest level of phenolic compounds were found in cloves, coriander, cumin, ginger, green cardamom, cinnamon and sweet laurel at $60^{\circ} \mathrm{C}$ as compared with 40 and $20^{\circ} \mathrm{C}$ as shown in Table 4 .

Table 4 also shows the effect of temperatures $\left(20,40\right.$ and $\left.60^{\circ} \mathrm{C}\right)$ on the total phenolic compounds content extracted by acetone. The data showed that there were significant differences in total phenolic compounds. At $60^{\circ} \mathrm{C}$, cloves and turmeric had the highest content of phenolic compounds (781.0 and 164.4 mg GAE/100g respectively). At $40^{\circ} \mathrm{C}$, cinnamon, cumin and sweet cumin had the highest levels of phenolics, values were 315.1 , 27.2 and $18.4 \mathrm{mg} \mathrm{GAE} / 100 \mathrm{~g}$ respectively. Also, at $20^{\circ} \mathrm{C}$; the total phenolics were for coriander, ginger, green cardamom, sumac and sweet laurel, values were 23.0, 41.5, 9.4, 754.5 and $18.3 \mathrm{mg}$ GAE/100g respectively as shown in Table 4. Increasing the temperature from 20, 40 and up to $60^{\circ} \mathrm{C}$ will increase the total phenolic compounds level from cloves and turmeric and that is in agreement with data reported previously [18].

Wojdylo et al. [19] studied the levels of phenolics for cinnamon, cloves and turmeric; he reported values of 0.13 for the cinnamon, 8.96 for cloves and $1.72 \mathrm{mg}$ GAE/100g for turmeric. These values are lower than values reported in the current investigation. 
The type of extractant for phenolic had been regarded as a major issue for researchers. Suhaj [20] found that different spices reacted in different manner with respect to the extractant type, for instance; methanol was the most suitable extractant for cloves while the ethanol (96\%) was best suitable for ginger. The cinnamon phenolics were extracted efficiently when $80 \%$ methanol with Soxhlet extraction were employed. The current investigations showed that acetone was a suitable extractant for cloves. On the other hand, ethanol was suitable to extract phenolics from ginger and that is in agreement with data reported previously [20].

Phenolic compounds reported for cloves, sumac and cinnamon found in agreement with similar values reported by Lin and Tang [21] on strawberry, green pepper and white onion.

\subsection{Antioxidant Activity (Radical Scavenging Activity)}

The scavenging of DPPH radicals was followed by monitoring the decrease in absorbance. IC $_{50}$ (the efficient concentration of spice extract in $\mathrm{mg} / \mathrm{ml}$ required to decrease initial DPPH radical concentration by $50 \%$ ) was obtained by interpolation from linear regression analysis. The higher DPPH radical scavenging activity is associated with a lower $\mathrm{IC}_{50}$ values (good antioxidant activity). Table 5 shows the antioxidant activity expressed as $\mathrm{IC}_{50}$ for the investigated spices. Antioxidant activity varied significantly among the spices, BHT was tested as reference synthetic antioxidant and showed the $50 \%$ inhibition at $0.0193 \mathrm{mg} / \mathrm{ml}$. For the investigated spices the lowest $\mathrm{IC}_{50}$ values were detected for cloves and cinnamon $(0.077$ and $0.09 \mathrm{mg} / \mathrm{ml}$, respectively). On the other hand, coriander and green cardamom had the highest values of IC $_{50}(1.051$ and $1.26 \mathrm{mg} / \mathrm{ml}$, respectively). The antioxidant activity expressed as $\mathrm{IC}_{50}$ for sumac, turmeric and sweet laurel did not vary significantly among the investigated spices $(0.150,0.160$ and $0.170 \mathrm{mg} / \mathrm{ml}$ respectively), from the antiradical activity (1/IC 50 ) in Table 5 , the top five spices according to their antioxidant activity properties are: cloves, cinnamon, sumac, turmeric and cumin, all spices had lower antioxidant activity than the reference antioxidant BHT, these values are in agreement with values reported by Ereifej et al. [18].

Data on total phenolic compounds presented in Table 4 suggest that the type of phenolic compounds rather than the amount is responsible for antioxidant activities [5] [22].

Al-Ismail et al. [23] studied the antioxidant activities for a set of plant extracts such as cumin, sumac, sweet cumin, sweet laurel and others; these extracts were obtained using the water and the ethanol extractants. Although the amount of phenolic compounds was high in sumac and cumin, these spices had low levels of antioxidant activities, which were attributed to the differences in type of phenolic compounds in each spice. Generally, it is suggested that it is difficult to compare between the antioxidant activities of spices without considering

Table 5. DPPH radical scavenging ( $\mathrm{IC}_{50}$ ) and antiradical activity values for the spices marketed in Jordan ${ }^{\mathrm{a}}$.

\begin{tabular}{|c|c|c|}
\hline Spices & $\mathrm{IC}_{50}(\mathrm{mg} / \mathrm{ml})^{\mathrm{b}}$ & 1/IC 50 (Antiradical activity) \\
\hline Cloves & $0.077^{\mathrm{g}}$ & $12.99^{\mathrm{b}}$ \\
\hline Coriander & $1.051^{\mathrm{b}}$ & $0.95^{\mathrm{d}}$ \\
\hline Cumin & $0.520^{\mathrm{e}}$ & $1.92^{\mathrm{d}}$ \\
\hline Ginger & $0.600^{\mathrm{d}}$ & $1.67^{\mathrm{d}}$ \\
\hline Green ardamom & $1.260^{\mathrm{a}}$ & $0.79^{\mathrm{d}}$ \\
\hline Turmeric & $0.160^{\mathrm{f}}$ & $6.25^{\mathrm{bcd}}$ \\
\hline Sumac & $0.150^{\mathrm{f}}$ & $6.67^{\mathrm{bcd}}$ \\
\hline Cinnamon & $0.090^{\mathrm{g}}$ & $11.11^{\mathrm{bc}}$ \\
\hline Sweet Cumin & $0.650^{\mathrm{c}}$ & $1.54^{\mathrm{d}}$ \\
\hline Sweet Laurel & $0.170^{\mathrm{f}}$ & $5.88^{\mathrm{cd}}$ \\
\hline BHT & $0.0193^{\mathrm{h}}$ & $51.81^{\mathrm{a}}$ \\
\hline LSDP $\leq 0.05$ & 0.041 & 6.98 \\
\hline
\end{tabular}

${ }^{\mathrm{a}}$ Means are average of two replicates and expressed as $\mathrm{mg} / \mathrm{ml} .{ }^{*}$ Means followed by different letters in the same column are significantly at $\mathrm{P} \leq 0.05$; ${ }^{\mathrm{b}} \mathrm{IC} \mathrm{C}_{50}$ is the efficient concentration of the test spices that scavenge (decrease) $50 \%$ of stable DPPH radical. 


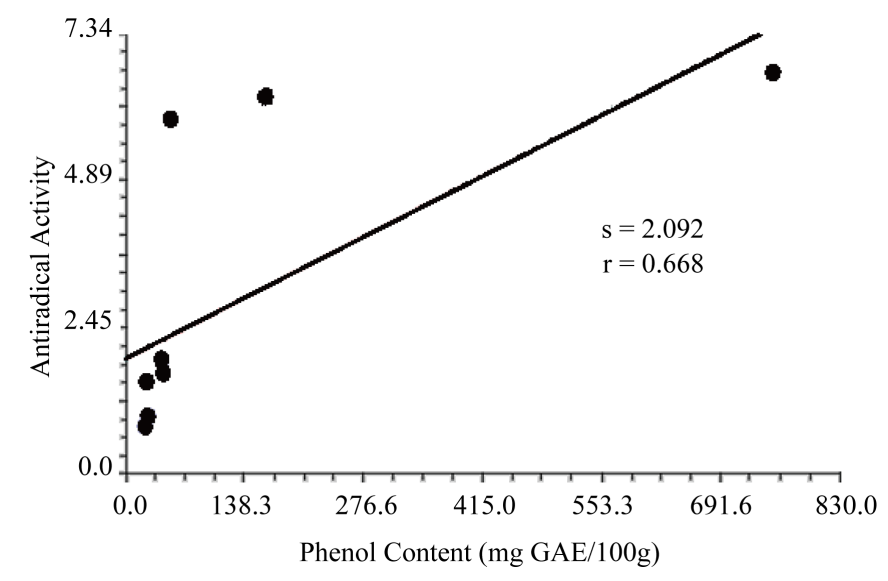

Figure 1. Relationship between total phenolic compounds content and the antiradical activity for the spices.

the extractant and extraction method as well as the types of phenolic compounds in spices.

Kaur and Kapoor [16] studied the antioxidant activity for ginger, coriander and turmeric. He found that the antioxidant activity ranged from 60 to $80 \%$. The current study reports that there was a relationship between the antioxidant activity and the total phenolic compounds content (Figure 1).

The antioxidant activity for cloves, sweet laurel, coriander, cinnamon and sweet cumin using percent of inhibition for DPPH approach was studied [24]. Our observations found to be in agreement with that reported by Politeo et al. [24].

Figure 1 shows the correlation between the antiradical activity and total phenolic compounds of the investigated spices, antiradical activity is $1 / \mathrm{IC}_{50}$ and directly proportional to the antioxidant activity. Positive correlation $(r=0.67)$ was found between antiradical activity and total phenolic compound levels.

\section{Conclusion}

In conclusion the level of phenolic compounds extracted by methanol, ethanol and acetone at $20^{\circ} \mathrm{C}, 40^{\circ} \mathrm{C}$, and $60^{\circ} \mathrm{C}$ varied significantly among the spices. The highest level of phenolics was obtained with methanol at $60^{\circ} \mathrm{C}$. The level of phenolics was increased when temperature was elevated from 20 to 40 and $60^{\circ} \mathrm{C}$. Cloves had the highest antioxidant activity whereas green cardamom and coriander had the lowest values. Antioxidant activity found to be positively correlated with total phenolic compounds.

\section{Acknowledgements}

The authors would like to acknowledge the financial support of the Scientific Research Deanship at Jordan University of Science and Technology.

\section{References}

[1] Kirk, R. and Sawyer, R. (1989) Pearson's Composition and Analysis of Foods. 9th Edition, Longman Scientific and Technical Publishing, London, Chapter 11, 391.

[2] Shobana, S. and Naidu, K. (2000) Antioxidant Activity of Selected Indian Spices. Journal of Prostaglandins Leukotrienes and Essential Fatty Acids, 62, 107-110. http://dx.doi.org/10.1054/plef.1999.0128

[3] Aruoma, O., Spencer, J., Rossi, R., Aeschbach, R., Khan, A., Mahmoud, N., Munoz, A., Murcia, A., Butler, J. and Halliwell, B. (1996) An Evaluation of the Antioxidant and Antiviral Action of Extracts of Rosemary and Provencal Herbs. Journal of Food Chemistry and Toxicology, 34, 449-456. http://dx.doi.org/10.1016/0278-6915(96)00004-X

[4] Mancini, J., Van Koiij, A., Mancini, DA., Cozzolino, F.F. and Torres, R.P. (1998) Antioxidant Activity of Cinnamon (Cinnamomum zeylanicum, Breyne) Extracts. Boll Chim Farm, 137, 443-447.

[5] Shahidi, F. and Naczk, M. (2004) Phenolic Compounds in Food and Nutraceuticals. CRC Press, Baco Raton, 313.

[6] Nishino, H., Tokuda, H., Satomi, Y., Masuda, M., Onozuka, M., Yamaguchi, S., Takayasu, J., Tsruta, J., Takemura, M., Li, T., Ichiishi, E., Kuchide, S., Okuda, M. and Murakoshi, M. (2000) Cancer Chemoprevention by Phytochemicals 
and Their Related Compounds. Asian Pacific Journal of Cancer Prevention, 1, 49-54.

[7] Asmi, D., Hong, Y., Barrett, D. and Mitchell, A. (2003) Comparison of the Total Phenolic and Ascorbic Acid Content of Freeze-Dried and Air-Dried Marionberry, Strawberry and Corn Grown Using Conventional, Organic and Sustainable Agricultural Practices. Journal of Agricultural and Food Chemistry, 51, 1237-1241. http://dx.doi.org/10.1021/jf020635c

[8] Lako, J., Trenerry, V., Wahlqvist, M., Wattanapenpaiboon, N., Sotheeswaran, S. and Premier, R. (2007) Phytochemical Flavonols, Carotenoids and the Antioxidant Properties of a Wide Selection of Fijian Fruit, Vegetables and Other Readily Available Foods. Journal of Food Chemistry, 102, 777-783. http://dx.doi.org/10.1016/j.foodchem.2006.01.031

[9] Kähkönen, M., Hopia, A., Vuorela, H., Rauha, J., Pihlaja, K., Kujala, T. and Heinonen, M. (1999) Antioxidant Activity of Plants Extracts Containing Phenolic Compounds. Journal of Agricultural and Food Chemistry, 47, 3954-3962. http://dx.doi.org/10.1021/jf990146l

[10] Pokorny, J., Yanishlieva, N. and Gordon, M. (2001) Antioxidants in Food: Practical Applications. CRC Press, Baco Raton, Chapters 1 and 3.

[11] Singleton, V. and Rossi, J. (1965) Colorimetry of Total Phenolic Compounds with Phosphomolybdic-Phosphotungstic Acid Reagents. American Journal of Enology and Viticulture, 16, 144-158.

[12] Matthäus, B. (2002) Antioxidant Activity of Extracts Obtained from Residues of Different Oilseeds. Journal of Agriculture Food Chemistry, 50, 3444-3452. http://dx.doi.org/10.1021/jf011440s

[13] SAS (2002) User's Guide. SAS Institute Inc., Cary.

[14] Hayouni, E., Abedrabba, M., Bouix, M. and Hamdi, M. (2007) The Effect of Solvents and Extraction Method on the Phenolic Compounds Contents and Biological Activities in Vitro of Tunisian Quercus coccifera L. and Juniperus phoenicea L. Fruit Extract. Journal of Food Chemistry, 105, 1126-1134. http://dx.doi.org/10.1016/j.foodchem.2007.02.010

[15] Hsu, B., Coupar, I. and Ng, K. (2006) Antioxidant Activity of Hot Water Extract from the Fruit of the Doum Palm, Hyphaene thebaica. Journal of Food Chemistry, 98, 317-328. http://dx.doi.org/10.1016/j.foodchem.2005.05.077

[16] Kaur, C. and Kapoor, H. (2002) Anti-Oxidant Activity and Total Phenolic Compounds Content of Some Asian Vegetables. International Journal of Food Science and Technology, 37, 153-161. http://dx.doi.org/10.1046/j.1365-2621.2002.00552.x

[17] Shan, B., Cai, Y., Brooks, J. and Corke, H. (2007) The in Vitro Antibacterial Activity of Dietary Spice and Medicinal Herb Extracts. International Journal of Food Microbiology, 117, 112-119. http://dx.doi.org/10.1016/j.ijfoodmicro.2007.03.003

[18] Ereifej, K.I., Feng, H., Rababah, T.M., Tashtoush, S.H., Al-U’datt, M.H., Al-Rabadi, G.J., Torley, P. and Alkasrawi, M. (2015) Microbiological Status and Nutritional Composition of Spices Used in Food Preparation. Food and Nutrition Sciences, 6, 1134-1140. http://dx.doi.org/10.4236/fns.2015.612118

[19] Wojdylo, A., Oszmianski, J. and Czemerys, R. (2007) Antioxidant Activity and Phenolic Compounds in 32 Selected Herbs. Journal of Food Chemistry, 105, 940-949. http://dx.doi.org/10.1016/j.foodchem.2007.04.038

[20] Suhaj, M. (2006) Spice Antioxidants Isolation and Their Antiradical Activity: A Review. Journal of Food Composition and Analysis, 19, 531-537. http://dx.doi.org/10.1016/j.jfca.2004.11.005

[21] Lin, J. and Tang, C. (2007) Determination of Total Phenolic and Flavonoid Contents in Selected Fruits and Vegetables, as Well as Their Stimulatory Effects on Mouse Splenocyte Proliferation. Journal of Food Chemistry, 101, 140-147. http://dx.doi.org/10.1016/j.foodchem.2006.01.014

[22] Rababah, T., Hettiarachchy, N. and Horax, R. (2004) Total Phenolic Compounds and Antioxidant Activities of Fenugreek, Green Tea, Black Tea, Grape Seed, Ginger, Rosemary, Gotu Kola and Ginkgo Extracts, Vitamin E and tert-Butylhydroquinone. Journal of Agricultural and Food Chemistry, 52, 5183-5186. http://dx.doi.org/10.1021/jf049645z

[23] AL-Ismail, K., Hamdan, M. and Al-Delaimy, K. (2006) Antioxidant and Anti Bacillus cereus Activities of Selected Plant Extracts. Jordan Journal of Agricultural Sciences, 2, 168-177.

[24] Politeo, O., Jukic, M. and Milos, M. (2006) Chemical Composition and Antioxidant Activity of Essential Oils of Twelve Spice Plants. Croatica Chemica Acta, 79, 545-552. 